\title{
Was the serine protease cathepsin G discovered by S. G. Hedin in 1903 in bovine spleen?
}

\author{
David Palesch1, Marcin Sieńczyk², Jozef Oleksyszyn², Michael Reich¹, Ewa Wieczerzak², \\ Bernhard O. Boehm ${ }^{1}$ and Timo Burster ${ }^{1 凶}$ \\ 1Division of Endocrinology and Diabetes, Department of Internal Medicine I, University Medical Center Ulm, Ulm, Germany; ${ }^{2}$ Wrocław University \\ of Technology, Wrocław, Poland; '3Faculty of Chemistry, University of Gdansk, Gdańsk, Poland
}

\begin{abstract}
In the beginning of the 20th century, enzymes with proteolytic activity were classified as peptidases, Erepsin, and proteases. Among these, pepsin, trypsin, and autolytic enzymes were of the protease class. Spleen-derived proteases were poorly characterized until Sven Gustaf Hedin performed several digestion experiments with bovine spleen. He incubated minced bovine spleen under acidic or neutral conditions and characterized two active proteases; the results were published in 1903. The first protease was named a-protease and was active under neutral conditions. The second was named $\beta$-protease and was active under acidic conditions. We replicated Hedin's experiments according to his methods and found, by using activity-based probes to visualize proteases, that the historical a-protease is the presentday serine protease cathepsin G (CatG), which is known to be important in several immune processes, including antigen processing, chemotaxis, and activation of surface receptors. The $\beta$-protease, however, comprised different proteases including CatX, B, S, and D. We suggest that Hedin described CatG activity in bovine spleen over 100 years ago.
\end{abstract}

Keywords: proteases, cathepsin, spleen cells, Hedin

Received: 02 July, 2010; revised: 10 November, 2010; accepted: 13 December, 2010; available on-line: 07 March, 2011

\section{INTRODUCTION}

Proteolytic enzymes are generally broadly classified as proteases, but in 1915, the classification of such enzymes was based on more specific substrates and included peptidases (digest polypeptides), Erepsin (digest peptones), and proteases (degrade proteins). Pepsin, trypsin, and autolytic enzymes were classified as proteases (Hedin, 1915). Towards the end of the 19th century, various scientists concentrated their research on autolytic enzymes. For example, in 1890, Salkowski found increased nitrogenous substances during long-term incubation of liver, muscles, and suprarenal glands at body temperature and interpreted his findings as the action of proteolytic enzymes in these tissues (Salkowski, 1890). Thirteen years later, the Swedish scientist Sven Gustaf Hedin extended Salkowski's results by treating minced bovine spleen with either neutral or acidic medium and analyzing the products of autodigestion. Hedin published his data in 1903, showing that bovine spleen cells harbor at least two different proteolytic enzymes, one active under neutral conditions, which he named $\alpha$-protease, and the other ac- tive under acidic conditions, which he named $\beta$-protease (Hedin, 1903a).

After discovering these two proteases in bovine spleen, Hedin performed further experiments with bovine serum and concluded that it contained a weak proteolytic enzyme active in neutral medium, the activity of which could be blocked by heating at $55^{\circ} \mathrm{C}$ or neutralized by antibodies (also named anti-enzymes at the time) present in the serum. Hedin assumed that the $\alpha$-protease in bovine spleen-derived leukocytes was similar to the protease found in serum. He further speculated that the $\alpha$-protease may derive from lysed leukocytes or leukocytes that secrete proteases (Hedin, 1903b).

In another experiment, Hedin mixed bovine pancreasderived trypsin with normal serum and added casein as a substrate. The serum had a neutralizing effect. Therefore, the data obtained were called Reihenfolgephänomen (i.e., order phenomenon), and the optimum temperature of neutralization was determined to be $37^{\circ} \mathrm{C}$ (Hedin, 1905). Hedin concluded that antibodies were necessary for the anti-tryptic activity because previous antibody publications had reported anti-tryptic effects (Landsteiner, 1900; Cathcart, 1904). Hedin defined a general principle by preincubating trypsin with serum at $37^{\circ} \mathrm{C}$ before adding the substrate. This successive procedure, which he established 100 years ago, is the standard protocol for biochemical inhibition of proteases.

Moreover, Hedin stated that inside leukocytes, proteases were involved in "digesting processes" (Hedin, 1903a). Phagocytosis, with credit given to Metchnikoff, appears intracellularly in so-called "digesting vacuoles" with acidic pH (Metchnikoff, 1884; 1901). The conclusions they proposed were precise and prophetic. Antigen processing occurs inside cells and is executed by proteases. A gastric mucosa protease was named cathepsin (gr. $x \alpha \theta \varepsilon \varphi \varepsilon i \nu$ to digest) and was proposed to have its origin in leukocytes in the late 1920s (Willstätter, 1929). Lysosomes were not discovered until 1955 (De Duve et al., 1955; Novikoff et al., 1956), and a $28 \mathrm{kDa}$ protease, active in alkaline $\mathrm{pH}$, named cathepsin $\mathrm{G}$ (CatG), was isolated from human spleen in 1976 (Starkey \& Barrett, 1976).

\footnotetext{
e-mail: timo.burster@uniklinik-ulm.de
}

Abbreviations: APC, antigen-presenting cells; Cat, cathepsin; DAP $\alpha$-aminoalkylphosphonate diphenyl ester; DDT, dithiothreitol; LHVS, morpholinurea-leucine-homophenylalanine-vinyl phenyl sulfone; PBMC, peripheral blood mononuclear cells; PMSF, phenylmethylsulfonyl fluoride; Suc-VPF, Suc-Val-Pro-PheP(OPh) ${ }_{2}$; ZRLR, Z-Arg-LeuArg-a-aza-glycyl-Ile-Val-OMe 
The function of cathepsins in the endocytic compartment (endosome and lysosome) within antigen-presenting cells (APC) is to digest antigens into antigenic peptides capable of binding to major histocompatibility complex (MHC) class II molecules. These MHC II antigenic peptide complexes migrate to the cell surface, activate respective $\mathrm{T}$ cells, and cause an immune response. Cysteine (CatB, C, F, H, S, X, V, L) and asparagine endoprotease (Watts et al., 2005; Turk \& Turk, 2009), serine (CatA (Reich et al., 2010) and CatG (Burster et al., 2010)), and apartyl (CatD and CatE) proteases are involved in antigen processing of different APC (for review, see Colbert et al., 2009). The serine proteases CatG, neutrophil elastase, and proteinase 3 are highly expressed in granulocytes and can be secreted into the blood by these cells under inflammatory conditions (Meier et al., 1985). CatG is important in the processing of antigens in primary APC (Reich et al., 2009a), has anti-bacterial capacity (Ohlsson et al., 1977), regulates chemotaxis (Nufer et al., 1999), activates the protease-activated receptor 4 (Sambrano et al., 2000), and is inhibited by thrombospondin 1 present in the serum or by serpins found in cells (Bornstein et al., 1991; Heutinck et al., 2010).

The spleen is the body's largest filter of blood and functions to promote the innate and adaptive immune response. The red pulp of the spleen is responsible for clean-up of older erythrocytes and effective iron recycling. The white pulp is formed by sheathed lymphoid tissue composed of $\mathrm{T}$ and $\mathrm{B}$ cell compartments that facilitate $\mathrm{T}$ cell interactions with dendritic cells (DC) and mediate $\mathrm{B}$ cell expansion, respectively. APC from the bloodstream enter the white pulp through the marginal zone and initiate a potent adaptive immune response. We replicated Hedin's 1903 experiment by analyzing protease activity after treatment of bovine spleen with neutral or acidic medium. Activity-based probes and Western blotting were used to determine the presence of cysteine, aspartyl, or serine proteases in the collected filtrates. We found that $\mathrm{Cat} G$ was abundant in the fraction which Hedin described as filtrate $\mathrm{B}\left(\mathrm{F}_{\mathrm{B}}\right.$; Fig. 1). Thus, we provide evidence, using several biochemical methods, that Hedin's $\alpha$-protease, first described in 1903, was most likely CatG. The $\beta$-protease described by Hedin reflected the activity of several proteases, including CatX, $\mathrm{B}, \mathrm{S}$, and D.

\section{MATERIALS AND METHODS}

Cells. Human peripheral blood mononuclear cells (PBMC) from buffy coats of healthy human cytomegalovirus-seronegative blood donors and bovine spleen cells were isolated by density gradient (Ficoll-Paque ${ }^{\mathrm{TM}}$ Plus, GE Healthcare, Uppsala, Sweden) centrifugation.

Preparation of bovine and murine spleens. Freshly isolated bovine, mouse (C57BL/6), or rat (Wistar) spleens were processed on the same day. The spleens were sliced and wire-extruded in phosphate-buffered saline (PBS) followed by incubation with $0.2 \%$ acetic acid $(\mathrm{pH} 4)$ for $16 \mathrm{~h}$ at room temperature. Subsequently, this acidic solution was filtered, and the filtrate (filtrate $\mathrm{A}$, $\mathrm{F}_{\mathrm{A}}$ ) was collected and frozen at $-20^{\circ} \mathrm{C}$ for further analysis. The residue (residue $A, R_{A}$ ) was incubated with $5 \%$ $\mathrm{NaCl}$ and adjusted to $\mathrm{pH} 7.0$ for another $16 \mathrm{~h}$ at $37^{\circ} \mathrm{C}$. This neutral solution was filtered, and the filtrate (filtrate $\mathrm{B}, \mathrm{F}_{\mathrm{B}}$ ) and residue (residue $\mathrm{B}, \mathrm{R}_{\mathrm{B}}$ ) were collected and stored at $-20^{\circ} \mathrm{C}$ for further use. The protein content of all filtrates was determined by Bradford assay.
Active site labeling and Western blotting. PBMC and spleen cells were lysed (10 mM Tris, $\mathrm{pH} 7.5,150$ $\mathrm{mM} \mathrm{NaCl}$, and $0.5 \% \mathrm{NP}-40)$ and adjusted to equal total protein concentration (quantified by Bradford assay), and $20 \mu \mathrm{g}$ of the cell lysate or filtrates were incubated with PBS ( $\mathrm{pH} 7.4$ ) in the presence of DAP (DAP22c, $2 \mu \mathrm{M})$ (Oleksyszyn \& Powers, 1991; Reich et al., 2009a). Alternatively, $5 \mu \mathrm{g}$ of cell lysate or filtrates were incubated with reaction buffer $(1 \mathrm{mM}$ EDTA, $50 \mathrm{mM}$ citrate, $\mathrm{pH} 5.0$, and $50 \mathrm{mM}$ DT'T) in the presence of DCG$04(10 \mu \mathrm{M}$; probe kindly donated by M. Bogyo, Stanford University, Palo Alto, CA, USA) (Greenbaum et al., 2000) for $1 \mathrm{~h}$ at room temp. Some of the samples were treated with CatG inhibitor I (CatG inhibitor, $10 \mu \mathrm{M}$, Calbiochem, Merck, Darmstadt, Germany), Suc-Val-Pro$\mathrm{Phe}^{\mathrm{P}}(\mathrm{OPh})_{2}$ (Suc-VPF, $10 \mu \mathrm{M}$, (Oleksyszyn and Powers, 1991)), Z-Arg-Leu-Arg- $\alpha$-aza-glycyl-Ile-Val-OMe $(10 \mu \mathrm{M}$, ZRLR, (Wieczerzak et al., 2007)), phenylmethylsulfonyl fluoride (PMSF, $2 \mathrm{mM}$, Sigma-Aldrich, Steinheim, Germany), or morpholinurea-leucine-homophenylalaninevinyl phenyl sulfone (LHVS, $20 \mathrm{nM}$, H. Kalbacher, University of Tübingen, Germany) and pre-incubated for $15 \mathrm{~min}$ at $37^{\circ} \mathrm{C}$. Purified CatG from human sputum was purchased from Sigma-Aldrich and $50 \mathrm{ng}$ was used in all experiments. Samples were resolved by $12 \%$ sodium dodecyl sulfate polyacrylamide gel electrophoresis (SDS/PAGE), blotted, and visualized using streptavidinhorseradish peroxidase (HRP, Vectastain, Burlingame, CA, USA). For Western blotting, $20 \mu \mathrm{g}$ of protein from crude cell extracts was loaded on SDS/PAGE, and the immune blot was performed using anti-CatD antibody (Calbiochem, Schwalbach, Germany) or anti-CatX (R\&D Systems, Wiesbaden, Germany). Anti- $\beta$-actin antibody and secondary HRP-conjugated antibodies were obtained from Sigma-Aldrich (Taufkirchen, Germany).

Determination of CatG activity. Kinetic measurement of CatG activity was accomplished by adding 15 $\mu \mathrm{g}$ of the indicated samples to the colorimetric substrate Suc-Val-Pro-Phe-pNA $(200 \mu \mathrm{M})$ in buffer $(0.5 \mathrm{M}$ $\mathrm{MgCl}_{2}$ in PBS, $\left.\mathrm{pH} 7.4\right)$. The colorimetric substrate was prepared as followed: Boc-Phe-OH (Iris-biotech, Marktredwitz, Germany) was reacted with $p$-nitro aniline to give starting Boc-Phe-pNA (Rijkers et al., 1995). Further deprotection steps and coupling were performed in solution using $50 \%$ trifluoroacetic acid (TFA, Iris-biotech) in dichloromethane (DCM, Iris-biotech) solution (for Boc deprotection) and O-benzotriazole- N,N,N',N'-tetramethyl-uronium-hexafluoro-phosphate (HBTU, as the coupling agent, Iris-biotech), respectively. Introduction of succinamide function was done by an application of succinic anhydride (Sigma-Aldrich, Poznań, Poland) in the presence of N,N-diisopropylethylamine (DIPEA, Iris-biotech). Final product was purified using HPLC chromatography (Econosphere ${ }^{\mathrm{TM}}$ C-18 column, Grace, Poznań, Poland). The enzyme assays were performed at $37^{\circ} \mathrm{C}$ in duplicate, and absorbance was determined at $405 \mathrm{~nm}$ (absorbance microplate reader, EL808, BioTek, Winooski, VT, USA).

\section{RESULTS AND DISCUSSION}

\section{Spleen preparation according to Hedin's protocol}

S. G. Hedin described two proteases, one active in acidic, and the other in neutral medium. For those studies, he incubated minced bovine spleen in 2 liters of $0.2 \%$ acetic acid for $16 \mathrm{~h}$ at room temp. Chloroform and toluol were added to the mixture in order to pre- 

A
1. minced
2. $16 \mathrm{~h}$ at room temperature, $0.2 \%$ acetic acid; $\mathrm{pH} 4$
chloroform and toluol to prevent fermentation 3. Filtration

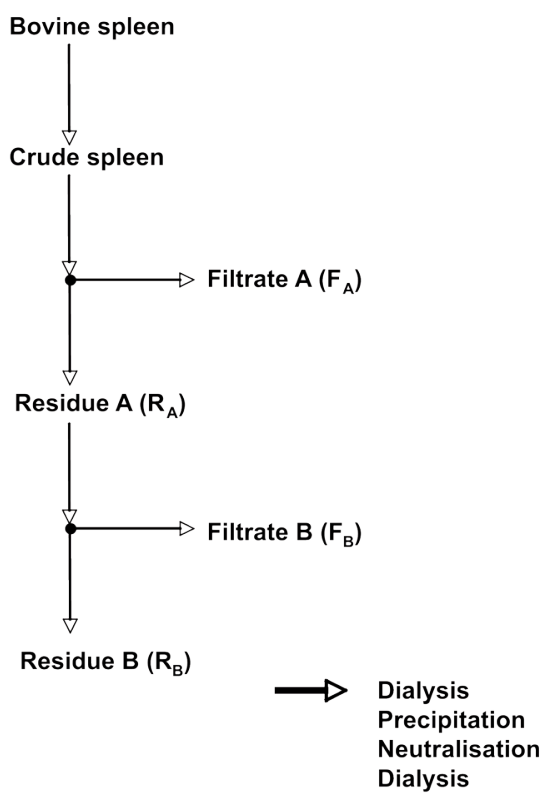

B

\section{Sliced and wire-extruded \\ 2. $16 \mathrm{~h}$ at room temperature, $0.2 \%$ acetic acid; $\mathrm{pH} 4$}

3. Filtration

4. $16 \mathrm{~h}$ at $37^{\circ} \mathrm{C}$

$5 \% \mathrm{NaCl} ; \mathrm{pH} 7$

5. Filtration

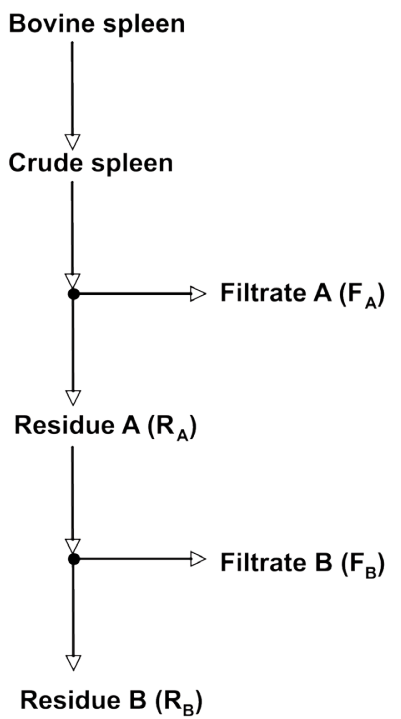

$\longrightarrow$ Active site-directed affinity labeling

Figure 1. Hedins's experiment in 1903

Sven Gustaf Hedin (1859-1933) was born on October 6, 1859, in Alseda, Jönköpings län, Sweden, and received his doctoral degrees in philosophy and medicine in 1886 and 1893, respectively, from Lund University. From 1900 to 1907 , he was at the Lister Institute of Preventive Medicine in London and became Professor in 1908 at Uppsala University. He was always interested in research on proteases and brought us an improved understanding of proteases involved in digestive processes and their inhibition. In 1903, he published his findings on bovine spleen proteases. (A) Outline of Hedins's experimental procedure. (B) Experimental procedure of the present study.

vent fermentation. Afterwards, the product was filtered to obtain residue $A\left(R_{A}\right)$ and filtrate $A\left(F_{A}\right)$ (Fig. 1A). $R_{A}$ was extensively washed with water until no acid reaction was acquired and finally, 2 liters of a $5 \% \mathrm{NaCl}$ solution was added for an additional $16 \mathrm{~h}$ at $37^{\circ} \mathrm{C}$. After this incubation, the fluid was filtered a second time to obtain $R_{B}$ and $F_{B}$. The protein degradation of filtrates $F_{A}$ and $F_{B}$ was determined with tannic acid, which precipitates peptones (a mixture of peptides and amino acids), allowing the volume of the precipitate before and after the incubation time to be quantified. The volume thus corresponds to the digestion and proteolytic activity in the respective samples.
In our experiments, whole, freshly isolated bovine spleen was wire-extruded and treated with acetic acid for $16 \mathrm{~h}$ (Fig. 1B). The fluid was filtered to obtain $\mathrm{R}_{A}$ and $\mathrm{F}_{\mathrm{A}} \cdot \mathrm{R}_{\mathrm{A}}$ was further treated with $\mathrm{NaCl}, \mathrm{pH}$-adjusted to 7.0 , and incubated for an additional $16 \mathrm{~h}$ at $37^{\circ} \mathrm{C} . \mathrm{F}_{\mathrm{A}}$ was directly prepared for analysis (Fig. 2). After $\mathrm{R}_{\mathrm{A}}$ incubation, the suspension was filtered into $R_{B}$ and $F_{B}$.

\section{Identification of active serine proteases in the respective filtrates}

To determine the content of active serine proteases in different filtrates, the same amount of protein from 
A

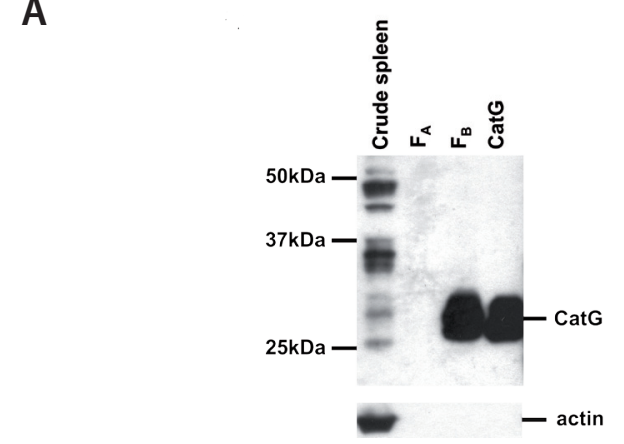

B

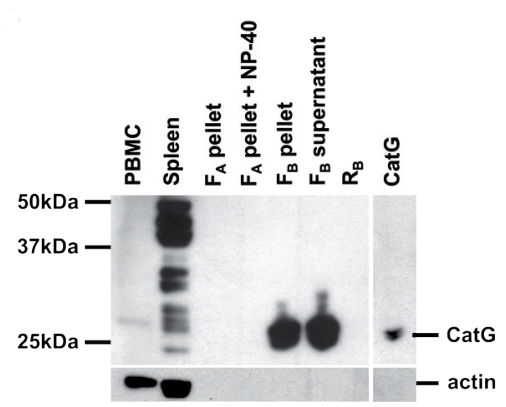

C

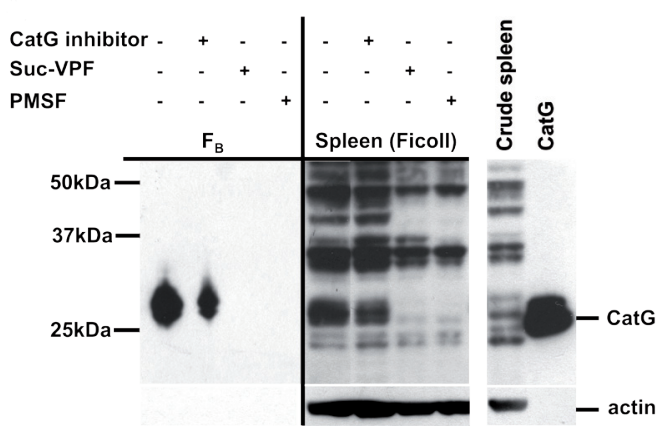

D

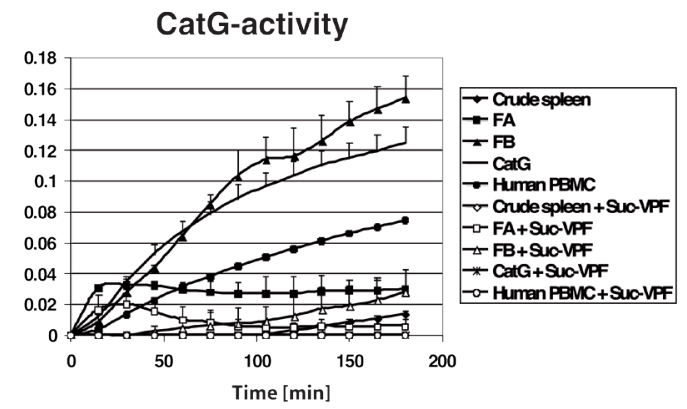

Figure 2. Active serine proteases in bovine spleen

(A and $\mathbf{B}$ ) Cell isolation and lysis were performed as described in the Methods section. Equal amounts of cell lysate of primary bovine spleen cells and bovine PBMC, respectively, were incubated with the activity-based biotinylated probe DAP and loaded onto SDS/PAGE. Active serine proteases were visualized by streptavidin-horseradish peroxidase (HRP) blot. Purified human CatG (50 ng) was used as control. $\beta$-Actin immunoblotting (45 kDa) was performed as a loading control. Data are representative of four experiments and two different spleens. (C) Cell lysates were preincubated with CatG inhibitor $(10 \mu \mathrm{M})$, Suc-VPF $(10 \mu \mathrm{M})$, and PMSF ( $2 \mathrm{mM}$ ) for $15 \mathrm{~min}$ at $37^{\circ} \mathrm{C}$. Equal amounts of cell lysate were incubated with the active site probe DAP and analyzed as above. Data are representative of at least two experiments using two different spleens. (D) CatG activity was measured using the colorimetric substrate Suc-VPF-pNA. Purified CatG (50 ng) was used as a positive control. Data are representative of one of two experiments, and the measurement was performed in duplicate. F, filtrate; R, residue. each sample was pre-incubated with the activity-based probe $\alpha$-aminoalkylphosphonate diphenyl ester (DAP). The phosphonate inhibitor DAP covalently binds to the active site serine residue of serine proteases and thus allows for visualization of active serine proteases via streptavidin-HRP labeling. Streptavidin functions as a bridge between HRP and biotin from DAP. Active CatG migrated at $28 \mathrm{kDa}$ in $\mathrm{F}_{\mathrm{B}}$, in contrast to the crude spleen extracts, in which we only detected low levels of CatG activity (Fig. 2A). Approximately $2.5 \mathrm{ng}$ of CatG was detected in $1 \mu \mathrm{g}$ of $\mathrm{F}_{\mathrm{B}}$, which was quantified by comparing a known amount of purified CatG (50 ng) with $F_{B}$. This indicates that $\mathrm{Cat} G$ is the predominant protease in this fraction. In $F_{A}$, CatG activity was not detectable. Notably, we did not detect $\beta$-actin in $F_{A}$ or $F_{B}$, most likely due to degradation by proteases during the incubation period specified by Hedin's protocol. In a separate experiment, fractions $F_{A}$ and $F_{B}$ were centrifuged to obtain cell pellets and supernatant to determine whether CatG could be detected in these fractions. Part of the $F_{A}$ pellet was treated with detergent (NP-40), and $\mathrm{F}_{\mathrm{B}}$ was separated into cell pellet and supernatant. However, we did not detect any CatG in $F_{A}$ treated with NP-40 or in $R_{B}$, and CatG activity did not differ between the $\mathrm{F}_{\mathrm{A}}$ pellet and $\mathrm{F}_{\mathrm{A}}$ supernatant (Fig. 2B). CatG activity in bovine spleen was then investigated in greater detail. We used the broadspectrum serine protease inhibitor phenylmethylsulfonyl fluoride (PMSF), a reversible CatG inhibitor (CatG inhibitor), or the irreversible CatG inhibitor Suc-ValPro-Phe $\mathrm{P}(\mathrm{OPh})_{2}$ (Suc-VPF). Both $\mathrm{F}_{\mathrm{B}}$ and Ficoll-purified spleen leukocytes were pre-incubated with the indicated inhibitors. CatG activity was completely inhibited by PMSF and SucVPF but not entirely by the reversible CatG inhibitor in either $F_{B}$ or Ficoll-purified spleen cells, which might account for the difference between human, mouse, and rat as compared to bovine CatG (Fig. 2C, Supplementary Data A). Inhibition of serine proteases by PMSF in the crude spleen extract demonstrated that different active serine proteases, migrating at 50, 45, 40, and $37 \mathrm{kDa}$, were present in this extract.

With further analysis using the colorimetric substrate Suc-VPF-pNA, we confirmed that CatG is active in $F_{B}$, but not in $\mathrm{F}_{\mathrm{A}}$, (Fig. 2D; for rat and mouse spleen, compare Supplementary Data A, B, and C). These results indicate that the serine protease migrating at $28 \mathrm{kDa}$ in $\mathrm{F}_{\mathrm{B}}$ is CatG.

\section{Determination of cysteine proteases and CatD}

Cysteine proteases were analyzed using a similar approach as described above. Biotinylated DCG-04, a cysteine protease inhibitor based on E64, was used to determine active CatX, B, H, S, and L/C. CatX, B, and $S$ were detected in $F_{A}$. In contrast, no active CatB, $S$, or $\mathrm{X}$ was found in $\mathrm{F}_{\mathrm{B}}$ (Fig. 3A). The allocation of a band to the respective active cathepsins was determined using the specific CatS inhibitor morpholinurea-leucinehomophenylalanine-vinyl phenyl sulfone (LHVS) (Riese et al., 1996) or the CatB-specific inhibitor ZRLR (Wieczerzak et al., 2007; Reich et al., 2009b) (Fig. 3B; for rat spleen, see Supplementary Data D). E64 was used as a broad cysteine protease inhibitor. Notably, the upper two bands refer to CatX, indicated in the Supplementary section showing the CatX immunoblot (Supplementary Data E).

Subsequently, the aspartyl protease CatD was analyzed using a CatD-specific immunoblot because of the lack of an active-site label for aspartyl proteases. CatD was 


\section{A, left panel}

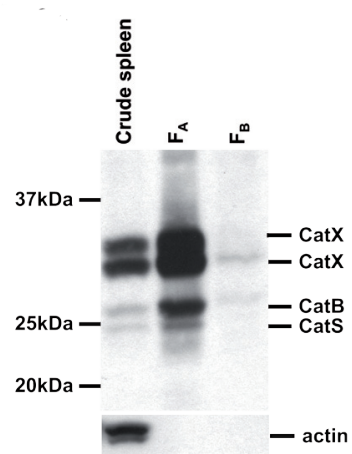

B

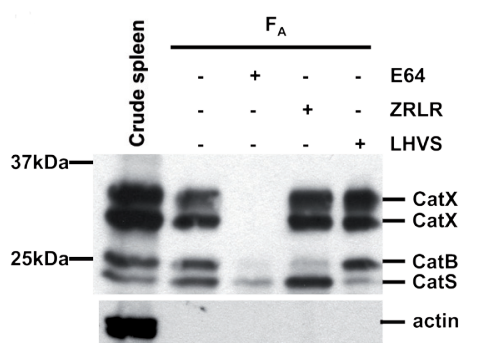

detected in $\mathrm{F}_{\mathrm{A}}$, but only a trace amount of the mature form of CatD was detected in $\mathrm{F}_{\mathrm{B}}$ (Fig. 4; Supplementary Data F). This demonstrates that several proteases, including CatX, CatB, CatS, and CatD, were present in $\mathrm{F}_{\mathrm{A}}$. Therefore, Hedin's $\beta$-protease consists of multiple proteolytic enzymes, explaining the observation of rapid proteolytic degradation in acidic fluid (Hedin, 1901). In a later publication, Hedin discussed this issue in more detail and concluded that other proteases active in the acidic medium were present (Hedin, 1923), which is consistent with our findings. Furthermore, treatment of crude spleen extract with acetic acid for $16 \mathrm{~h}$ and for an additional $16 \mathrm{~h}$ under neutral conditions resulted in Cat $G$ enrichment in $F_{B}$, suggesting that Hedin's protocol was also practical for concentrating CatG. Notably, Hedin's experimental design of protease inhibition was utilized to categorize inhibitors into anti-enzymes (i.e., antibodies), Hemmungskörper (i.e., blocking body), or inhibitive substances (Hedin, 1915). The mechanism was explained by absorption as experiments with Kieselgur revealed that the $\alpha$-protease was not active when bound to Kieselgur (Hedin, 1907). Another possible explanation for the inhibition is the interaction of normal serum with the protease (Hedin, 1905). Indeed, Hedin found that only the bovine spleen-derived $\alpha$-protease, in contrast to $\beta$-protease, was inhibited by antibodies in bovine

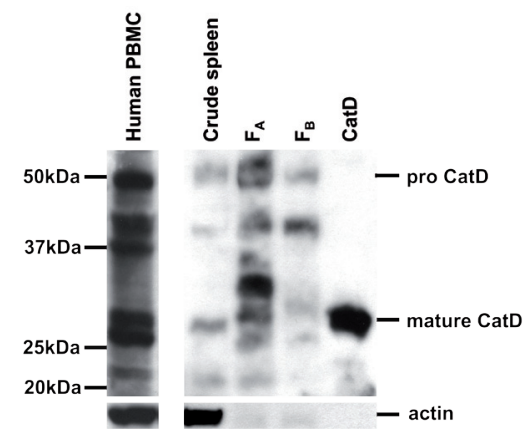

Figure 4. CatD expression in bovine spleen cells CatD was visualized by immunoblot with anti-human CatD. Purified human CatD was used as control. One of three experiments, each with similar results, is shown.

\section{A, right panel}

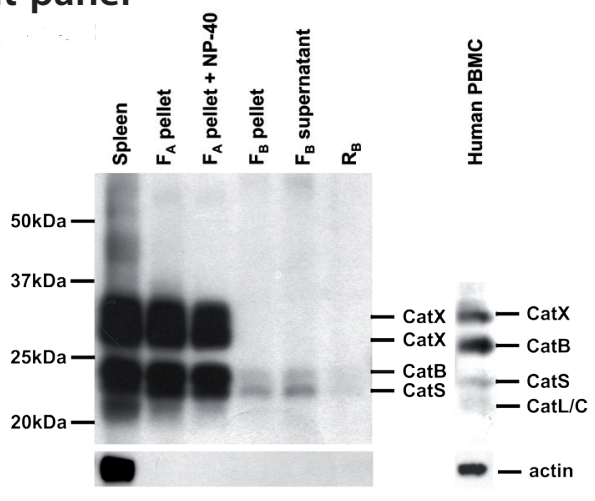

Figure 3. Active cysteine proteases in bovine spleen

(A) Bovine spleen extracts were labeled with the active site probe DCG-04 and visualized by HRP blot. The identity of the cysteine proteases was deduced from side-by-side comparisons to cell lysate from primary human PBMC and (B) by using the cathepsin-specific inhibitors ZRLR $(10 \mu \mathrm{M})$, LHVS $(20 \mathrm{nM})$, and the broad cysteine protease inhibitor E64 $(10 \mu \mathrm{M})$ for $15 \mathrm{~min}$ at $37^{\circ} \mathrm{C}$. One representative activity blot is shown from two independent experiments.

serum and was not neutralized under his experimental conditions (Hedin, 1903a). The effect he described was most likely the action of serine protease inhibitors (serpins and thrombospondin 1) circulating in the blood (Remold-O'Donnell et al., 1992). Today, we know that CatG in leukocytes, such as DC and B cells, is not only important in antigen processing, but also in immune defense in the periphery. In conclusion, based on several criteria, we suggest that Hedin described CatG activity in 1903 as the $\alpha$-protease active in neutral medium.

\section{Acknowledgements}

This work was supported by grants from the Deutsche Forschungsgemeinschaft (SFB 518, GRK 1041-2) to B.O.B. and the State Committee for Scientific Research, Poland (grant N405 342633) to M.S. We gratefully acknowledge M. Bogyo for providing DCG-04 and Metzgerei Span for providing freshly isolated bovine spleens.

\section{REFERENCE}

Bornstein P, O'Rourke K, Wikstrom K, Wolf FW, Katz R, Li P, Dixit VM (1991) A second, expressed thrombospondin gene (Thbs2) exists in the mouse genome. J Biol Chem 266: 12821-12824.

Burster T, Macmillan H, Hou T, Boehm BO, Mellins ED (2010) Cathepsin G: Roles in antigen presentation, beyond. Mol Immunol 47: 658-665.

Cathcart EP (1904) On the antitryptic action of normal serum. J Physiol 31: 497-506.

Colbert JD, Matthews SP, Miller G, Watts C (2009) Diverse regulatory roles for lysosomal proteases in the immune response. Eur J Immunol 39: 2955-2965.

De Duve C, Pressman BC, Gianetto R, Wattiaux R, Appelmans F (1955) Tissue fractionation studies. 6. Intracellular distribution patterns of enzymes in rat-liver tissue. Biochem J 60: 604-617.

Greenbaum D, Medzihradszky KF, Burlingame A, Bogyo M (2000) Epoxide electrophiles as activity-dependent cysteine protease profiling, discovery tools. Chem Biol 7: 569-581.

Hedin SG (1901) Ueber ein proteolytisches Enzym in der Milz. HoppeSeyler's Z Physiol Chem 32: 341-349.

Hedin SG (1903a) Investigations on the proteolytic enzymes of the spleen of the ox. J Physiol 30: 155-175.

Hedin SG (1903b) On the presence of a proteolytic enzyme in the normal serum of the ox. J Physiol 30: 195-200.

Hedin SG (1905) On the antitryptic action of serum-albumin. I Physiol 32: 390-394. 
Hedin SG (1907) A case of specific adsorbtion of enzymes. Biochem J 2: $112-116$.

Hedin SG (1915) Grundzuege der Physikalischen Chemie in ihrer Beziehung zur Biologie. Verlag von JF Bergmann, Wiesbaden.

Hedin SG (1923) Die Proteolytischen Enzyme der Lymphdruesen. Hoppe Seyler's Z Physiol Chem 125: 289-296.

Heutinck KM, Ten Berge IJ, Hack CE, Hamann J, Rowshani AT (2010) Serine proteases of the human immune system in health, disease. Mol Immunol 47: 1943-1955.

Landsteiner K (1900) Zur Kenntnis der antifermentativen, lytischen und agglutinierenden Wirkungen des Blutserums und der Lymphe. Zentbl f Bakt Orig 27: 357-362.

Meier HL, Heck LW, Schulman ES, MacGlashan DW Jr (1985) Purified human mast cells, basophils release human elastase, cathepsin $\mathrm{G}$ by an IgE-mediated mechanism. Int Arch Allergy Appl Immunol 77: 179-183.

Metchnikoff E (1884) Über die pathologische Bedeutung der intrazellulären Verdauung. Fortschr Med 17: 558-569.

Metchnikoff E (1901) L'immunite dans les maladies infectieuses. pp 600, Paris, Masson.

Novikoff AB, Beaufay H, De Duve C (1956) Electron microscopy of lysosome-rich fractions from rat liver. J Biophys Biochem Cytol 2: 179-184.

Nufer O, Corbett M, Walz A (1999) Amino-terminal processing of chemokine ENA-78 regulates biological activity. Biochemistry 38: 636-642.

Ohlsson K, Olsson I, Spitznagel K (1977) Localization of chymotrypsin-like cationic protein, collagenase, elastase in azurophil granules of human neutrophilic polymorphonuclear leukocytes. Hoppe Seylers Z Physiol Chem 358: 361-366.

Oleksyszyn J, Powers JC (1991) Irreversible inhibition of serine proteases by peptide derivatives of (alpha-aminoalkyl)phosphonate diphenyl esters. Biochemistry 30: 485-493.

Reich M, Lesner A, Legowska A, Sienczyk M, Oleksyszyn J, Boehm BO, Burster T (2009a) Application of specific cell permeable cathepsin $G$ inhibitors resulted in reduced antigen processing in primary dendritic cells. Mol Immunol 46: 2994-2999.
Reich M, Wieczerzak E, Jankowska E, Palesch D, Boehm BO, Burster $\mathrm{T}$ (2009b) Specific cathepsin B inhibitor is cell-permeable, activates presentation of TTC in primary human dendritic cells. Immunol Lett 123: 155-159.

Reich M, Spindler KD, Burret M, Kalbacher H, Boehm BO, Burster T (2010) Cathepsin A is expressed in primary human antigen-presenting cells. Immunol Lett 128: 143-147.

Remold-O’Donnell E, Chin J, Alberts M (1992) Sequence, molecular characterization of human monocyte/neutrophil elastase inhibitor. Proc Natl Acad Sci USA 89: 5635-5639.

Riese RJ, Wolf PR, Bromme D, Natkin LR, Villadangos JA, Ploegh HL, Chapman HA (1996) Essential role for cathepsin S in the MHC class II-associated invariant chain processing, peptide loading. Immunity 4: 450-453.

Rijkers DT, Wielders SJ, Tesser GI, Hemker HC (1995) Design, synthesis of thrombin substrates with modified kinetic parameters. Thromb Res 79: 491-499.

Salkowski E (1890) Zeitschr f klin Med 17: 77.

Sambrano GR, Huang W, Faruqi T, Mahrus S, Craik C, Coughlin SR (2000) Cathepsin $G$ activates protease-activated receptor-4 in human platelets. I Biol Chem 275: 6819-6823.

Starkey PM, Barrett AJ (1976) Human cathepsin G: Catalytic, immunological properties. Biochem J 155: 273-278.

Turk B, Turk V (2009) Lysosomes as "suicide bags" in cell death: myth or reality? I Biol Chem 284, 21783-21787.

Watts C, Matthews SP, Mazzeo D, Manoury B, Moss CX (2005) Asparaginyl endopeptidase: case history of a class II MHC compartment protease. Immunol Rev 207: 218-228.

Wieczerzak E, Rodziewicz-Motowidlo S, Jankowska E, Gieldon A, Ciarkowski J (2007) An enormously active, selective azapeptide inhibitor of cathepsin B. J Pept Sci 13: 536-543.

Willstätter R (1929) Über die Proteasen der MagenschleimhautErste Abh, lung über die Enzyme der Leukocyten. Hoppe-Seyler's Z Physiol Chem 180: 127-143. 